\title{
"Assessing and strengthening budgetary security of regions and their amalgamated hromada in an unstable economy: A case for Ukraine"
}

\begin{tabular}{|c|c|}
\hline AUTHORS & $\begin{array}{l}\text { Halyna Voznyak (D) } \\
\text { R } \\
\text { Olha Mulska (D) } \\
\text { R } \\
\text { Taras Kloba (D) } \\
\text { Lev Kloba (D) }\end{array}$ \\
\hline ARTICLE INFO & $\begin{array}{l}\text { Halyna Voznyak, Olha Mulska, Taras Kloba and Lev Kloba (2021). Assessing } \\
\text { and strengthening budgetary security of regions and their amalgamated hromada } \\
\text { in an unstable economy: A case for Ukraine. Public and Municipal Finance, } \\
\text { 10(1), 138-150. doi:10.21511/pmf.10(1).2021.11 }\end{array}$ \\
\hline DOI & http://dx.doi.org/10.21511/pmf.10(1).2021.11 \\
\hline RELEASED ON & Monday, 01 November 2021 \\
\hline RECEIVED ON & Friday, 03 September 2021 \\
\hline ACCEPTED ON & Wednesday, 27 October 2021 \\
\hline LICENSE & $\begin{array}{l}(c) \mathrm{EY}^{\mathrm{EY}} \\
\text { This work is licensed under a Creative Commons Attribution } 4.0 \text { International } \\
\text { License }\end{array}$ \\
\hline JOURNAL & "Public and Municipal Finance" \\
\hline ISSN PRINT & $2222-1867$ \\
\hline ISSN ONLINE & $2222-1875$ \\
\hline PUBLISHER & LLC "Consulting Publishing Company "Business Perspectives" \\
\hline FOUNDER & LLC "Consulting Publishing Company "Business Perspectives" \\
\hline$\sigma^{\circ}$ & $\begin{array}{l}\text { 三ニ } \\
\text { 三: }\end{array}$ \\
\hline NUMBER OF REFERENCES & NUMBER OF FIGURES \\
\hline 28 & 4 \\
\hline
\end{tabular}

(c) The author(s) 2021. This publication is an open access article. 


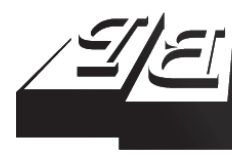

\section{BUSINESS PERSPECTIVES}

0

LLC "CPC "Business Perspectives"

Hryhorii Skovoroda lane, 10,

Sumy, 40022, Ukraine

www.businessperspectives.org

Received on: $3^{\text {rd }}$ of September, 2021

Accepted on: $27^{\text {th }}$ of October, 2021

Published on: $1^{\text {st }}$ of November, 2021

(๑) Halyna Voznyak, Olha Mulska, Taras Kloba, Lev Kloba, 2021

Halyna Voznyak, Doctor of Economics, Leading researcher, Department of Regional Financial Policy, M. Dolishniy Institute of Regional Research of National Academy of Sciences of Ukraine, Ukraine. (Corresponding author)

Olha Mulska, Ph.D. in Economics, Senior researcher, Department of Social and Humanitarian Development of Regions, M. Dolishniy Institute of Regional Research of National Academy of Sciences of Ukraine, Ukraine.

Taras Kloba, Postgraduate Student, M. Dolishniy Institute of Regional Research of National Academy of Sciences of Ukraine, Ukraine.

Lev Kloba, Ph.D. in Economics, Associate Professor, Department of Finance, Accounting and Analysis, Institute of Entrepreneurship and Advanced Technologies, Lviv Polytechnic National University, Ukraine.
Halyna Voznyak (Ukraine), Olha Mulska (Ukraine), Taras Kloba (Ukraine), Lev Kloba (Ukraine)

\section{ASSESSING AND STRENGTHENING BUDGETARY SECURITY OF REGIONS AND THEIR AMALGAMATED HROMADA IN AN UNSTABLE ECONOMY: A CASE FOR UKRAINE}

\begin{abstract}
An essential determinant of the economic growth of regions and amalgamated hroma$\mathrm{da}$ is budgetary security, the weakening of which causes the strengthening of financial imbalances of territories and the emergence of budget risks and threats in different time lags. The paper aims to assess budgetary security of regions and amalgamated hromada in Ukraine in an unstable economy. The assessment of budgetary security and risks of areas and amalgamated hromada is carried out based on a multidimensional statistical analysis of budget indicators, calculation of the aggregate indicator of budget risks, and the level of budgetary security by a multiplicative method. The study sample included the regions of Ukraine and 22 amalgamated hromada in terms of cities of regional significance, urban, township, and rural territorial assemblies, which are represented by different areas in Ukraine. According to the assessment, Poltava, Kyiv, Zaporizhzhia, Dnipropetrovsk, and Mykolaiv oblasts are characterized by a low level of budget risks, which indicates high budget stability. On the other hand, the strengthening of budget imbalances, deterioration of the strength of local budgets, in particular in 2019-2020 in urban amalgamated hromada (Druzhbivska and Malovyskivska (68 points)); in village areas (Malynivska (5 points), Steblivska (7-7 points)); in rural amalgamated hromada (Chmyrivska 8-7 points)). The study results can serve as an analytical basis in the practice of local governments in the development and justification of regional and local budget policies, the nature of inter-budgetary relations, the formation of regional development strategies, etc.
\end{abstract}

\section{Keywords}

budget, risk, threats, security, regions, amalgamated hromada, Ukraine, limit values, policy

JEL Classification

$\mathrm{H} 71, \mathrm{H} 72, \mathrm{O} 18$

\section{INTRODUCTION}

Transformational changes in the economy of Ukraine in recent years (financial and economic crisis of 2014-2015, reforms in the public finance system, sectoral reforms, military aggression by the Russian Federation, the spread of the COVID-2019 pandemic, which had a significant impact on all spheres of society) hurt the financial capacity of local budgets and the ability of local governments to exercise their powers and implement development strategies. Consequently, they exacerbated new challenges and threats to the sustainable progress of regions and amalgamated hromada. Furthermore, unprecedented steps to counter the spread of the pandemic (restriction of certain types of production and commercial activities, resulting in reduced economic activity, the introduction of remote forms of work and education, strengthening the role of public administration in emergencies, etc.), exacerbated by growing uncertainty at all levels of government. In 
addition, these steps forced the government to revise not only economic growth forecasts but also to change approaches to the formation of long-term priorities for the development of regions and amalgamated hromada.

Decentralization reform has exacerbated the emergence of significant financial problems, as well as budget risks in the regions and amalgamated hromada, in particular:

1) reduction of revenues to local budgets compared to the planned (even though in 2020 there was a slight increase $-5.4 \%$ compared to 2019 on the general fund) due to the decline in business activity and a significant reduction in intergovernmental transfers from the state budget;

2) increasing pressure on local budgets due to the need to finance additional measures to overcome the pandemic and socio-economic consequences (according to the Accounting Chamber of Ukraine, in 2020 local budgets allocated a total of 10.3 billion UAH for measures related to the COVID-2019 pandemic, which is $2.1 \%$ of local budget expenditures);

3) loss of revenue from the payment for land due to the provision by the state of tax benefits under these taxes (exemption for March-April 2020) without compensation for such losses.

Such trends have led to a violation of the financial stability of regions and amalgamated hromada, the restoration of which would minimize the harmful risks and challenges and ensure the susceptibility of a changing economy to new opportunities for development. Therefore, the key to restoring the financial balance and the defining dominant of balanced economic growth of territories is to ensure budgetary security, adequately constructed algorithm for assessing which at the regional and local levels will restore economic stability and monitor financial threats and risks.

\section{LITERATURE REVIEW}

In recent years, issues of budgetary security, its strengthening, assessing, managing risks that pose a threat have been the subject of research by experts and scientists. The reasons for excessive attention to this phenomenon are systemic and local financial and economic crises, which lead to deepening budget differentiation of territories, the need to improve public financial management (as a result - increasing transparency and predictability of fiscal policy), aligning their distribution with state and regional policy; improving the system of state regulation of socio-economic processes and improving the quality of public services. However, to the scientific discourse, there is no single universal method of assessing the budgetary security of regions and amalgamated hromada, which is the reason for the lack of information and analytical support for the implementation of budget policy and relevant financial management policy, including budget risks. In particular, some methods of assessing budgetary security were used at the level of enterprises and the state, and the evaluation algorithm is based on the assumption that budgetary security is a driver of economic growth of the state, an indicator and criterion for the effectiveness of budget policy (Kolisnyk, 2011). Instead, Kuznetsova et al. (2014) developed an approach to assessing budgetary security based on the assumption that budgetary security weakens with increasing financial inequality, social instability, labor market virtualization, and increasing economic turbulence. Thus, the factors identified by scientists are indicators of assessing the financial risks and budgetary security of the territory, exceeding the limit values of which leads to a violation of economic stability.

Ensuring a high level of budgetary security of the state requires the argumentation of an appropriate methodological approach, taking into account the processes of globalization and decentralization. Varenyk (2015) tested the methodology for assessing the budgetary security of regions and budget risks associated with financial shocks, which is based on determining the level of protection of the economic system from the effects of internal 
and external threats. Thus, a high level of protection of the territory is achieved due to the ability of the authorities to generate sufficient budgetary resources to perform their functions, ensure the sustainability of the main parameters of the regional financial system, attract and use borrowed funds to finance budget expenditures. In addition, it is necessary to promote the economic growth of regions and amalgamated hromada.

Budgetary security assessment based on the planning approach is carried out as an algorithm to ensure budget efficiency. The high level of efficiency of the budget plan indicates a low level of budget risks and a high level of budgetary security, and vice versa. On the other hand, the deposit is a crucial indicator of the imbalance of the financial plan of local authorities, confirms the deficit of territory in financial assets, and shows inadequate sources of revenue generation and vectors of their redistribution (Byhovchenko \& Pichkur, 2019; Cherniavska et al., 2020). Budgetary security is a category of guaranteeing the absence of budget risks and threats. Therefore, assessing budget stability as a condition for security through the determinants of the ratio of budget items is the basis of the methodology by Shkarlet et al. (2019). Budgetary security is an existential characteristic that is transformed under the influence of various external factors (Wood et al., 2019; Romenska et al., 2020; Kwilinski et al., 2020). Therefore, its evaluation and study of the effectiveness of fiscal policy depend on the implementation of fiscal decentralization, the efficacy of regional expenditure planning, as well as monitoring and forecasting budget indicators in the focus of analyzing business activity in the territory (Kafka et al., 2019; Rushchyshyn et al., 2021).

Lysiak et al. (2020) investigated the threshold values of budgetary security of regions and amalgamated hromada in the context of increasing global challenges. They focused on the assessment of financial and economic risks, on the counteraction of which depends on the ability of the economic system to anticipate threats to the budget sphere, and, consequently, to achieve the established parameters of budgetary stability of the territory. As a result of a comprehensive analysis of budgetary security and risks, it was argued that the methodology for assessing budgetary security, including threats, should be based on empirical indicators that reflect the level of stability of local budgets and indicate a high level of productivity of budget funds. Thus, the methodology of assessing budgetary security, based on the empirical indicator of the sustainability of local budgets, allows planning activities to increase the effectiveness of a fiscal policy, which is the key to adhering to the innovative economic growth model.

The use of budget risk assessment methods based on indicators of economic development and financial stability allows central and local governments to ensure the achievement of the planned level of economic and financial goals (Lupak et al., 2021; Cassar \& Gibson, 2008), as well as a high level of economic development of the country, regions, and amalgamated hromada. Heath et al. (2013) argue that the method of assessing budgetary security using the empirics of sustainability of local budgets is an information-analytical tool for implementing the country's economic growth policy, a means of forming regional financial monitoring. Furthermore, achieving budgetary security allows the territories to quickly realize economic goals, ensure the social interests of the population, and create a favorable business environment and investment climate.

Gorina (2013) proves that the financial security of regions and amalgamated hromada is determined by the ability of local governments to meet their obligations to provide services to the population, ensuring a satisfactory financial condition of the provincial budget in the short and long term. Accordingly, a comprehensive methodology for assessing budgetary security should be based on financial stability, self-sufficiency, autonomy, and efficiency indicators. The basis of the developed method is the calculated integrated indicator to measure the efficiency of expense and income parts of local budgets. Denek and Dylewski (2013) argue that budgetary security can generate sufficient revenue and is a way to meet social spending commitments in regions and amalgamated hromada. Therefore, their methodological algorithm is based on the balance sheet method of assessing budget risks, thresholds of financial stability, and fiscal security. In return, Steccolini et al. (2015) prove the practicality of including financial risks in assessing budgetary security following the im- 
plementation of the territory's cyclical and structural financial obligations. Lucianelli et al. (2018) supplemented the methodology for assessing budgetary security based on developing a system of structural commitments such as economic and sectoral changes, business activity, internal market transformations, and expanding sources of local budget revenues. The ability of amalgamated hromada and regions to influence the processes of minimizing budget risks and ensuring budgetary security increases the efficiency and resilience of local budgets to external turbulence. Interregional commitments arise from loans from regional financial institutions and government allocations, which affect local economic opportunities. This increases with the appropriate choice of passive or active fiscal policy. Accordingly, passive budgetary security provides the ability to respond to crises, i.e., the ability to return to the current state. In contrast, operational security helps react to threats and overcome them through economic development and new financial opportunities.

Voznyak and Pelekhatyy (2018) proposed the latest methods of assessing the budgetary security of regions in the projection of participatory instruments. They highlighted the advantages of using the method of participation in the budget process and stressed the importance of assessing potential risks of financial systems divergence and regional budget planning. The deepening of regional economic imbalances leads to a decrease in budgetary stability, weakening of budgetary security and are drivers of increasing budget risks (Voznyak et al., 2019), which necessitates a comprehensive assessment of financial threats, monitoring of which will ensure the stability of the economic system.

Assessment of budgetary security of the territory based on indicative method, dynamic analysis, expert review, optimization, pattern recognition, multidimensional statistical analysis is most common in the articles of Ukrainian scientists (Babets, 2013; Pazdnykova et al., 2019; Heiets et al., 2006). An innovative approach to assessing budgetary security and risks with an integrated system of indicators was developed and tested by Karanina et al. (2020). They proved the existence of close interaction between the economic and financial security of territories, as well as the need to minimize budget risks to ensure sustainable development of national security. A practical approach to assessing budgetary security is to use the method of acceptable budget risk.

The developed methods of assessing budgetary security and risks can serve as an information and analytical basis for the implementation of the financial and budgetary policy. However, the results obtained on their level of risks and security do not fully justify current financial instruments to achieve economic stability, minimize threats, ensuring sustainable development of the national economy. In this regard, it is imperative to assess budget risks in the regional context, particularly in the projection of amalgamated hromada, the impact of fiscal stability on economic growth, and develop a methodological algorithm for assessing budget risks as a criterion for violating budgetary security. Therefore, the increase in fiscal risks leads to increasing financial instability as a threat to weaken the budgetary security of territories (regions, amalgamated hromada).

The purpose of the paper is to assess the budgetary security of regions and amalgamated hromada in Ukraine and substantiate the directions of its strengthening in conditions of economic instability.

\section{METHODS}

The initial stage of assessing the budgetary security of regions and amalgamated hromada, the impact of budget risks on regional economic development, and thus identifying the relationship between the effectiveness of fiscal policy and economic growth of the country, regions, and amalgamated hromada is to obtain an empirical indicator of budgetary security. Therefore, a system of indicators was selected to construct useful indicators of budgetary security levels (Table 1). The design for assessing the budgetary security of territories is formed taking into account the criteria of accessibility in statistical databases, the complexity of reflecting the processes of formation and implementation of budget policy of regions, universality, and limitation of values. Deviation from the thresholds indicates an increase in negative trends and financial instability, hence the weakening of budgetary security. 
Source: Authors' development.

Purpose: an aggregate assessment of the state of budget security of territories

Objective: identification of budgetary risks that under the influence of certain factors may pose a threat to the financial security of territories

1st stage
$\begin{aligned} & \text { Formation of a system of indicators } \\ & \text { felection of primary indicators and evaluation horizon; analysis of sample representativeness; substantiation of } \\ & \text { the system of indicators }\end{aligned}$
the system of indicators

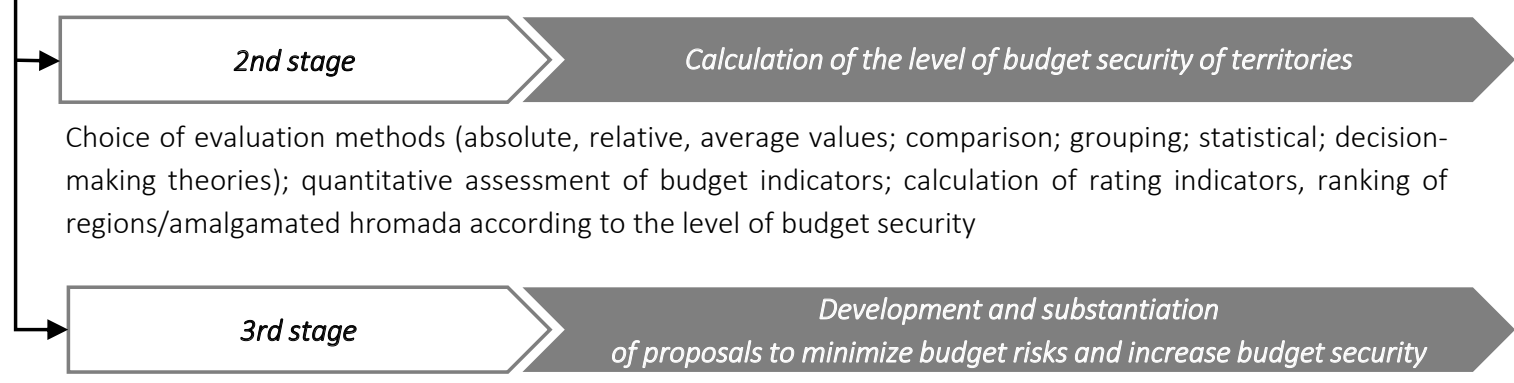

Interpretation of results; identification of problems, assessment of the influence of factors; making managerial decisions: setting funding priorities, transparent budget planning, etc.

Figure 1. Stages of assessing the budgetary security of territories

Table 1. System of indicators for assessing the budgetary security of territories

Source: Systematized by the authors.

\begin{tabular}{|c|c|c|}
\hline Indicators & Characteristics & Unit indicators \\
\hline Coefficient of budget balance & The degree of coverage of expenditures by income & \multirow{6}{*}{$\begin{array}{l}\text { 1. Revenues of local budgets (total, with } \\
\text { transfers, without transfers), thousand UAH; } \\
\text { 2. Expenditures of local budgets (total, with } \\
\text { transfers, without transfers), thousand UAH; } \\
\text { 3. The population of the territory, thousand } \\
\text { persons; } \\
\text { 4. Total transfers (grants, subventions), } \\
\text { thousand UAH; } \\
\text { 5. Tax revenues, thousand UAH; } \\
\text { 6. Non-tax revenues, thousand UAH }\end{array}$} \\
\hline Coefficient of budgetary security & Total expenditures per capita & \\
\hline Budget performance ratio & $\begin{array}{l}\text { The total amount of local budget revenues per } \\
\text { capita }\end{array}$ & \\
\hline Coefficient of budget independence & $\begin{array}{l}\text { The degree of budgetary independence of local } \\
\text { budgets from transfers from the state budget }\end{array}$ & \\
\hline Grant factor & $\begin{array}{l}\text { Dependence of local budgets on funding from the } \\
\text { state budget }\end{array}$ & \\
\hline $\begin{array}{l}\text { Coefficient of budgetary stability of } \\
\text { local budgets }\end{array}$ & $\begin{array}{l}\text { The ability of local governments to finance current } \\
\text { expenditures with revenues without transfers }\end{array}$ & \\
\hline
\end{tabular}

The information base for the study of budgetary security is the data of the State Statistics Service of Ukraine, the Ministry of Finance of Ukraine, including data from the Open Budget Portal, the State Treasury Service of Ukraine, and the Departments of Finance of regional state administrations. The stages of the methodological approach to assessing the budgetary security of territories are schematically presented in Figure 1.

Threats to budgetary security lead to the emergence of such budget risks as an imbalance of budget coverage (revenues will not provide expenditures); deterioration of budgetary security (reduction of expenditures per capita); reduction of budget effi- ciency (reduction of incomes per capita); reduction of budgetary autonomy (reduction of own financial resources); strengthening the subsidies of local budgets and violating the sustainability of local budgets. Accordingly, the limit values are separated by zones (low (0 points) / medium (1 point) / high (2 points) risk). Scoring budget risks and application cluster analysis will allow forming a typology of regions (amalgamated hromada) with different degrees of budgetary security. Accordingly, budgetary security zones are divided into three areas: absolute security zone (budget risks are minimal or absent), relative security zone (budget risks are insignificant), and high-risk zone (maximum level of budget risks) (Table 2). 
Table 2. Assessment indicators of budget risks and zones of budgetary security of regions (amalgamated hromada)

\begin{tabular}{|c|c|c|c|c|}
\hline \multirow{2}{*}{ Budget risks } & \multirow{2}{*}{ Formula } & \multicolumn{3}{|c|}{ Budgetary security zones } \\
\hline & & Absolute security & Relative security & Increased danger \\
\hline $\begin{array}{l}\text { Risk of imbalance of local } \\
\text { budgets }\end{array}$ & $K_{1}=D / V$ & \multirow{7}{*}{$\begin{array}{c}\text { Risks are minimal, socio- } \\
\text { economic development } \\
\text { of the territory is stable, } \\
\text { budget dependence on } \\
\text { external sources is low, own } \\
\text { revenues are tough and } \\
\text { sufficient }\end{array}$} & \multirow{7}{*}{$\begin{array}{l}\text { Chances are insignificant, } \\
\text { economic growth of } \\
\text { the region is not steady, } \\
\text { although there is a margin } \\
\text { of "strength," financial } \\
\text { and economic activity } \\
\text { is negligible, there is a } \\
\text { subsidy for local budgets } \\
\text { of individual anti-terrorist } \\
\text { operation }\end{array}$} & \multirow{7}{*}{$\begin{array}{l}\text { There is a high level of } \\
\text { budget risks, reserves } \\
\text { of economic growth are } \\
\text { exhausted, own revenues of } \\
\text { local budgets are declining, } \\
\text { there are excessive subsidies }\end{array}$} \\
\hline $\begin{array}{l}\text { Risk of reduced budgetary } \\
\text { security }\end{array}$ & $K_{2}=V / N$ & & & \\
\hline $\begin{array}{l}\text { The risk of reduced budget } \\
\text { performance }\end{array}$ & $K_{3}=D / N$ & & & \\
\hline $\begin{array}{l}\text { Risk of reduced budget } \\
\text { independence }\end{array}$ & $K_{4}=D_{t} / D$ & & & \\
\hline $\begin{array}{l}\text { Risk of increasing subsidies } \\
\text { for local budgets }\end{array}$ & $K_{5}=T / D$ & & & \\
\hline $\begin{array}{l}\text { Risk of violation of the } \\
\text { stability of local budgets }\end{array}$ & $K_{6}=D t / T$ & & & \\
\hline $\begin{array}{l}\text { The total risk of the } \\
\text { territory }\end{array}$ & & & & \\
\hline
\end{tabular}

Note: $D$ - total income of the region/community; $V$ - total expenditures/amalgamated hromada; $N$ - number of inhabitants of the region/community; $D t$ - income without transfers; $T$ - transfers.

Table 3. Limit values of budget risks: regions and amalgamated hromada

Source: Authors' calculations.

\begin{tabular}{|c|c|c|c|c|c|c|}
\hline \multirow{3}{*}{ Budget risks } & \multicolumn{6}{|c|}{ Limit value } \\
\hline & \multicolumn{3}{|c|}{ Amalgamated hromada } & \multicolumn{3}{|c|}{ Regions } \\
\hline & $\begin{array}{c}\text { Low } \\
0 \text { points }\end{array}$ & $\begin{array}{c}\text { Average } \\
1 \text { point }\end{array}$ & $\begin{array}{c}\text { High } \\
2 \text { points }\end{array}$ & $\begin{array}{c}\text { Low } \\
0 \text { points }\end{array}$ & $\begin{array}{l}\text { Average } \\
1 \text { point }\end{array}$ & $\begin{array}{c}\text { High } \\
2 \text { points }\end{array}$ \\
\hline $\begin{array}{l}\text { Risk of local budget } \\
\text { imbalance }\end{array}$ & $\geq 1.02$ & $1.02-1.001$ & $\leq 1.001$ & $\geq 1.03$ & $1.03-0.99$ & $\leq 0.99$ \\
\hline $\begin{array}{l}\text { Risk of reduced budgetary } \\
\text { security }\end{array}$ & $\geq 9,762.44$ & $9,762.44-9,015.51$ & $\leq 9,015.51$ & $\geq 13,622.82$ & $\begin{array}{l}13,622.82- \\
8,322.29\end{array}$ & $\leq 8,322.29$ \\
\hline $\begin{array}{l}\text { The risk of reduced budget } \\
\text { performance }\end{array}$ & $\geq 9753.7$ & $9,753.7-9,182.92$ & $\leq 9,182.92$ & $\geq 13,507.14$ & $\begin{array}{l}13,507.14- \\
8,574.67\end{array}$ & $\leq 8,574.67$ \\
\hline $\begin{array}{l}\text { Risk of reduced budget } \\
\text { independence }\end{array}$ & $\geq 0.59$ & $0.59-0.53$ & $\leq 0.53$ & $\geq 0.61$ & $0.61-0.41$ & $\leq 0.41$ \\
\hline $\begin{array}{l}\text { Risk of increasing subsidies for } \\
\text { local budgets }\end{array}$ & $\geq 0.47$ & $0.47-0.41$ & $\leq 0.41$ & $\geq 0.59$ & $0.59-0.39$ & $\leq 0.39$ \\
\hline $\begin{array}{l}\text { Risk of violation of the local } \\
\text { budget stability }\end{array}$ & $\geq 1.94$ & $1.94-1.39$ & $\leq 1.39$ & $\geq 1.71$ & $1.71-0.72$ & $\leq 0.72$ \\
\hline
\end{tabular}

Based on the aggregate assessment of the state of budgetary security of the regions, the gradation of budget risks was carried out. Limit values of budget risks are determined for each indicator for the area and the community in the selected time range, derivation of the arithmetic mean for each hand in terms of the year, and comparison with the minimum and maximum values (Table 3 ).

\section{RESULTS}

The limit values were determined by calculating the selected indicators for each of the regions of
Ukraine for the period 2016-2020, deriving the arithmetic mean value in terms of the year and comparing it with the minimum and maximum values. Thus, the rating assessment of the regions of Ukraine is formed by the total values of budget risk indicators (Figure 2).

During the study period, Poltava, Kyiv, Zaporizhzhia, Dnipropetrovsk, Kharkiv (except for 2016), and Mykolaiv are characterized by a stable, low level of budget risks. The total index of budget risks in any year did not exceed the threshold value; local budgets of these regions are balanced (only in 2019-2020 a slight deterioration in the value 


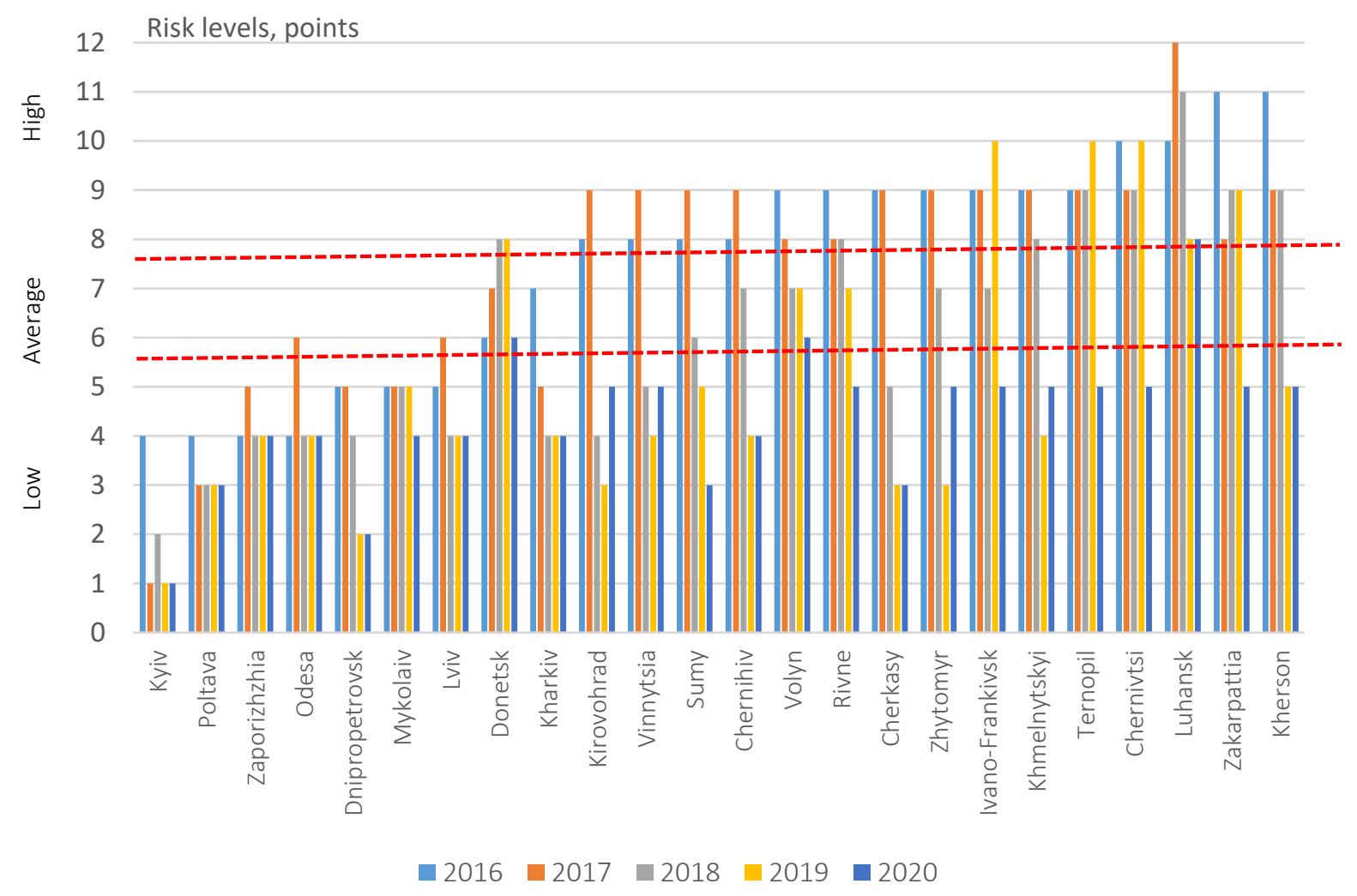

Note: Calculated by the multiplicative method.

Figure 2. Budget risks of the regions of Ukraine, 2016-2020

of budget coverage (97-99\%)). Furthermore, these regions showed a steady improvement in budget performance and low transfer dependence. Stably high revenues of local budgets, supported by the high potential of socio-economic development of these regions, which ensured their "stay" in the zone of absolute budgetary security. It should be noted that in 2020 in financially stable areas, significantly reduced revenues to local budgets of the leading regions (which was typical for most parts of Ukraine) compared to 2019, due to both the effects of the pandemic and the reduction of intergovernmental transfers. It is noticeable that the regions with a consistently high level of budgetary security during the analyzed period were two more oblasts: Lviv and Odesa. Only in 2017, these two regions fall into the zone of relative danger due to a slight deterioration in the stability of local budgets (Lviv) and budget coverage (Odesa). Thus, the results confirm the thesis that financially viable and economically "powerful" regions, whose expenditures are fully covered by revenues, carry minimal budget risks, can withstand external threats, and thus ensure their development.
In 2020, there was an ambiguous situation regarding the formation of fiscal policy at the regional level. Despite the existing challenges and pessimistic forecasts for reducing sources of revenue to local budgets, they have managed to strengthen their financial positions and the level of budgetary security (Table 3 ). Thus, in 2019, four oblasts had fully balanced budgets (K_1 $\geq 1)$, and in 2020 there were 12 such regions (!). Interestingly, higher growth rates of local budget revenues (excluding transfers) were shown by economically weaker parts (Zakarpattia, Volyn, Kirovohrad, Rivne, Ternopil, Khmelnytskyi, Chernivtsi, Chernihiv) (according to the monitoring of socio-economic development of areas in January-December 2020). In this regard, domestic trends do not coincide with the world practices of local budgets, which in 2020 experienced a significant decline in revenues. The undisputed leader in the level of budgetary security as in 2017 (1 point), and in 2020 (1 point) is the Kyiv region.

About the regions that form the zone of relative budgetary security, it should be noted that there 
Table 4. Grouping of regions by the level of budgetary security, 2016-2020

\begin{tabular}{|c|c|c|c|c|c|}
\hline \multirow{2}{*}{$\begin{array}{l}\text { Budgetary } \\
\text { security } \\
\text { zone }\end{array}$} & \multicolumn{5}{|c|}{ Years } \\
\hline & 2016 & 2017 & 2018 & 2019 & 2020 \\
\hline $\begin{array}{l}\hat{E}_{b s} \leq 5 \\
\text { (absolute } \\
\text { security) }\end{array}$ & $\begin{array}{c}\text { Dnipropetrovsk, } \\
\text { Zaporizhzhia, Kyiv, } \\
\text { Lviv, Mykolaiv, Odessa, } \\
\text { Poltava }\end{array}$ & $\begin{array}{c}\text { Dnipropetrovsk, } \\
\text { Zaporizhzhia, Kyiv, } \\
\text { Mykolaiv, Poltava, } \\
\text { Kharkiv }\end{array}$ & $\begin{array}{c}\text { Vinnytsia, } \\
\text { Dnipropetrovsk, } \\
\text { Zaporizhia, Kyiv, } \\
\text { Kirovohrad, Lviv, } \\
\text { Mykolaiv, Odesa, } \\
\text { Poltava, Kharkiv, } \\
\text { Cherkasy }\end{array}$ & $\begin{array}{c}\text { Vinnytsia, } \\
\text { Dnipropetrovsk, } \\
\text { Zhytomyr, } \\
\text { Zaporizhzhia, Kyiv, } \\
\text { Kirovohrad, Lviv, } \\
\text { Mykolaiv, Odesa, } \\
\text { Poltava, Sumy, } \\
\text { Kharkiv, Kherson, } \\
\text { Khmelnytskyi, } \\
\text { Cherkasy, Chernihiv }\end{array}$ & $\begin{array}{l}\text { Vinnytsia, } \\
\text { Dnipropetrovsk, } \\
\text { Zhytomyr, Zakarpattia, } \\
\text { Zaporizhzhia, Ivano- } \\
\text { Frankivsk, Kyiv, } \\
\text { Kirovohrad, Lviv, } \\
\text { Mykolaiv, Odesa, } \\
\text { Poltava, Rivne, } \\
\text { Sumy, Ternopil, } \\
\text { Kharkiv, Kherson, } \\
\text { Khmelnytskyi, } \\
\text { Cherkasy, Chernivtsi, } \\
\text { Chernihiv }\end{array}$ \\
\hline $\begin{array}{l}6 \leq K_{b s} \leq 7 \\
\text { (relative } \\
\text { safety) }\end{array}$ & Donetsk, Kharkiv & Donetsk, Lviv, Odesa & $\begin{array}{l}\text { Volyn, Zhytomyr, } \\
\text { Ivano-Frankivsk, } \\
\text { Sumy, Chernihiv }\end{array}$ & Volyn, Rivne & Volyn, Donetsk \\
\hline $\begin{array}{l}8 \leq K_{b s} \leq 12 \\
\text { (increased } \\
\text { danger) }\end{array}$ & $\begin{array}{l}\text { Vinnytsia, Volyn, } \\
\text { Zhytomyr, Zakarpattia, } \\
\text { Ivano-Frankivsk, } \\
\text { Kirovohrad, Luhansk, } \\
\text { Rivne, Sumy, } \\
\text { Ternopil, Kherson, } \\
\text { Khmelnytskyi, } \\
\text { Cherkasy, Chernivtsi, } \\
\text { Chernihiv } \\
\end{array}$ & $\begin{array}{l}\text { Vinnytsia, Volyn, } \\
\text { Zhytomyr, Zakarpattia, } \\
\text { Ivano-Frankivsk, } \\
\text { Kirovohrad, Luhansk, } \\
\text { Rivne, Sumy, } \\
\text { Ternopil, Kherson, } \\
\text { Khmelnytskyi, } \\
\text { Cherkasy, Chernivtsi, } \\
\text { Chernihiv }\end{array}$ & $\begin{array}{l}\text { Donetsk, Zakarpattia, } \\
\text { Luhansk, Rivne, } \\
\text { Ternopil, Kherson, } \\
\text { Khmelnytskyi, } \\
\text { Chernivtsi }\end{array}$ & $\begin{array}{c}\text { Donetsk, Zakarpattia, } \\
\text { Ivano-Frankivsk, } \\
\text { Luhansk, Ternopil, } \\
\text { Chernivtsi }\end{array}$ & Luhansk \\
\hline
\end{tabular}

are no stable and unchanging areas with low budget risks in contrast to the location of absolute security. Thus, in 2017, due to the deterioration of the stability of local budgets in this area were Lviv and Odesa regions (although they are among the top ten areas with high economic development potential). On the other hand, since 2018, the Volyn region has slightly improved budgetary security, which has ensured a permanent "stay" in the zone of relative budgetary security. In addition, it should be noted the region, which is developing dynamically and has significantly improved its financial position during the analyzed period, in the Zhytomyr region (from 9 points in 2016 to 3 in 2019).

Financial decentralization has led to an increase in local budget revenues, the tax capacity of regions with low levels of economic development, and the strengthening of the financial self-sufficiency of the leading regions in terms of budgetary security. Noteworthy is that the Luhansk region is a constant outsider during the selected research horizon in terms of budgetary security: the total budget risk ratio in 2016 is 10 points, in $2017-12$ points, and $2020-8$ points. Almost all risks threaten budgetary security, local budg- ets are unstable, and are characterized by excessive subsidies. Objectively, this situation is due to both destructive factors related to the challenges posed by Russia and internal factors (loss of human capital, low investment attractiveness, loss of industrial potential, loss of traditional markets, etc.), which ultimately does not strengthen positive trends macroeconomic growth, which have emerged since 2016. The high level of budget risks is inherent in the group of regions with low indicators of socio-economic development (from 6 to 12 points, depending on the area and year): Zakarpattia, Ivano-Frankivsk, Rivne, Chernivtsi, and Kherson. It is also noteworthy that in 20192020 most regions strengthened their positions in budgetary security, confidently shifting to relative and absolute security (Table 4).

The reasons for this situation are the reduction of transfer dependence on the state budget, poor planning of local budgets and underestimation of forecasts in terms of revenue generation, slowing growth of current investment expenditures.

To assess budgetary security at the local level, amalgamated hromada were selected in cities of regional significance, urban settlements, and 
rural territorial assemblies, representing different Ukrainian regions. The time was the last two years (2019-2020, before and during the pandemic). That amalgamated hromada formed in the initial stages of financial decentralization reform, and the first elections had already taken place by 2019 were deliberately chosen. As in the case of the regions, it has been suggested that threats to budgetary security may carry the same budget risks.

The amalgamated hromada of Ukraine demonstrates different levels of budgetary security, which is explained by the asymmetry of socio-economic development. Thus, the lowest budget risks are inherent in cities of regional importance (Lviv, Odesa, and Cherkasy). During the analyzed period, their budgetary security has not changed, even though in 2020, the most significant decline in revenues was recorded in the local budgets of large cities (Figure 3). Thus, high budgetary security and efficiency balanced the risks of increasing dependence and sustainability of local budgets in these cities. All this may indicate stable and sufficient revenues of such appropriations, low budget dependence on external sources, and the ability to meet external challenges and ensure their progress.
Similar trends are observed in such urban amalgamated hromada as Pyriatyn and Tyachiv; the total value of the budget risk indicator did not exceed 2 and 4 ponts, respectively. Thus, despite the significant impact of quarantine measures and over-financing expenditures to combat COVID-19 from local budgets, these areas are in the zone of absolute budgetary security due to substantial economic potential (in the Pyriatyn community, a significant part is formed by processing industry and agriculture).

Weakening of economic activity with a still sufficient "margin of safety," strengthening of budget imbalances, deterioration of the stability of local budgets, etc., are the characteristics of amalgamated hromada present in each selected group. Thus, for example, in 2019-2020 in the Ministry of Health (Chernivtsi (5 points), Chernihiv (5 points, respectively)); in urban amalgamated hromada (Druzhbivska (6-8 points, respectively), Malovyskivska (8-6 points, respectively); in settlements (Malynivska (5-5 points, respectively), Steblivska (7-7 points, respectively); in rural amalgamated hromada (8-7 issues respectively).

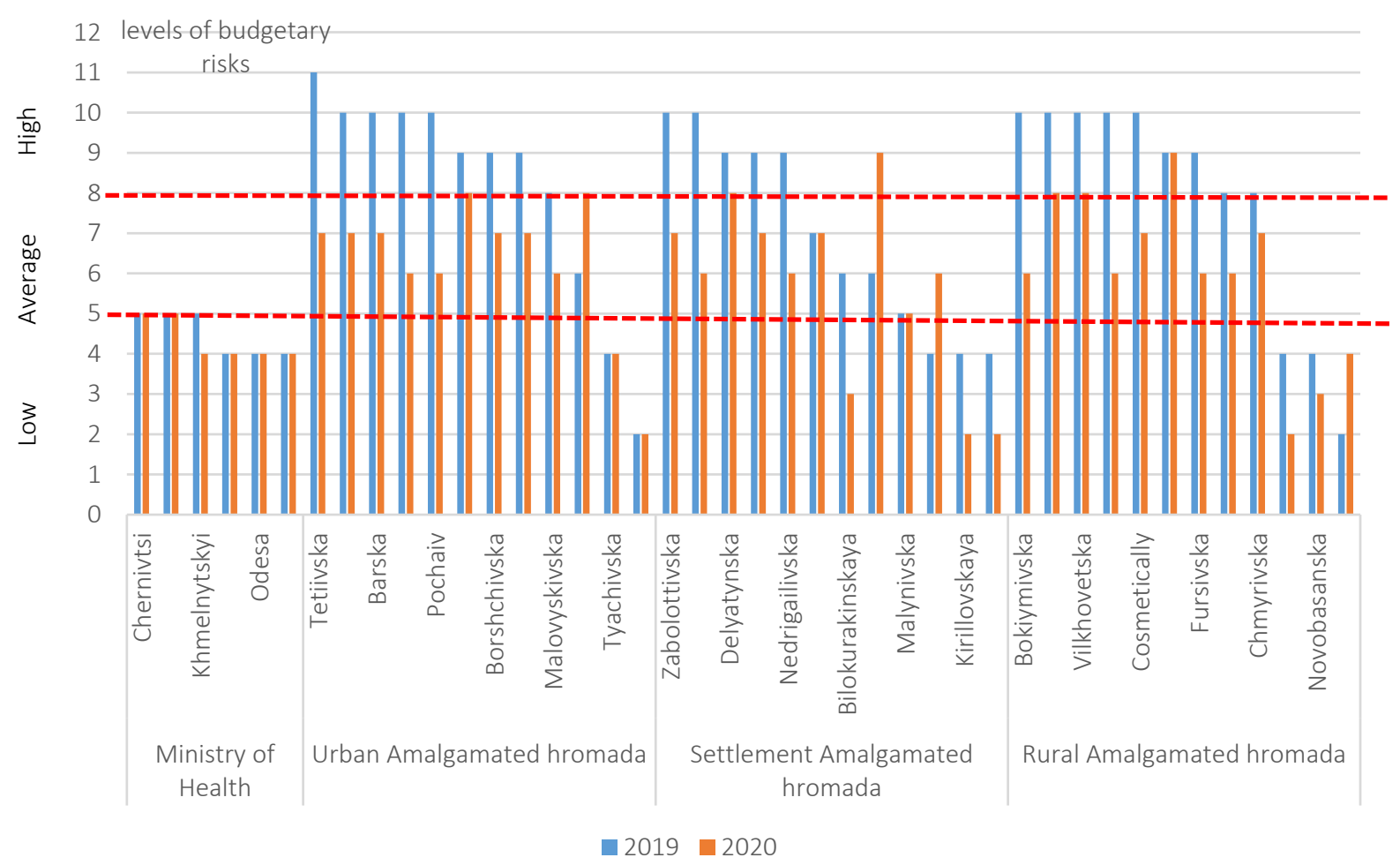

Note: Ministry of Health - cities of regional significance; $\mathrm{AH}$ - Amalgamated hromada.

Figure 3. Budget risks of amalgamated hromada of Ukraine, 2019-2020. 
The majority of amalgamated hromada in each selected group (except the Ministry of Health) in 2020 managed to improve their financial and economic situation, and hence the level of budgetary security (in the total sample of 22 (or 52.4\%)). This happened despite the decline business activity due to quarantine restrictions, despite funding for measures to combat COVID-19, loss of PIT revenue due to a reduction in the number of employees (which was most likely offset by annual wage growth), and loss of income from land fees and tax on real estate (through legislative decisions of public authorities).

Such trends reduce local budget expenditures of various kinds (from the capital to social), applying the postulates of behavioral economics. In increased risk and uncertainty, local governments have begun to avoid financial troubles, and management decisions have become savings rather than investment. Since 2020, most local budgets have managed to increase their revenues, which is a direct consequence of the reform of financial decentralization, and, consequently, strengthening the territories' budgetary security.

Some amalgamated hromada, such as the rural Shehynivska in the Lviv region, is in a zone of constant increased danger; in particular, all budget risks (excessive subsidies and deteriorating budgetary security and efficiency) pose a threat to the community's budgetary security. Among the amalgamated hromada that have significantly worsened in 2020 compared to 2019, their financial situation, and whose budget policy needs to be improved, is represented by such districts as Oleksandrivska village territorial community (from 6 to 9 points) and Irshanska (from 4 to 6 points)). Features of the first community - located in the Donetsk region - have an agricultural type of economy and a low level of budget efficiency. Therefore, all budget risks pose a threat to the community's budgetary security.

\section{DISCUSSION}

Certain budget risks that threaten the financial security of territories arise at different stages of the budget process. To minimize/level them, and it is vital to establish the nature of the occurrence in time, which will provide prospects for progress, including omissions of legal and financial nature, poor quality planning of local budgets, improper performance of control functions, and budget management functions, government miscalculations, implementing state regulatory policy, etc. Among the most significant risks to the budgetary security of the regions is the reduction of budget autonomy, strengthening the subsidies of local budgets, and violating the stability of local budgets. For rural amalgamated hromada, the most significant is the risk of imbalance of budget coverage.

Therefore, the effectiveness of overcoming threats to the budgetary security of regions and amalgamated hromada depends on the information and analytical basis for monitoring budget risks, including the approved unified methodology for assessing the debt security of areas, the established database of indicators to evaluate budgetary security of locations, etc. Among the areas of strengthening budgetary security at the regional or local level are those that will help reduce budget risks, and thus economic growth in general:

- strengthening the independence of local budgets and improving the efficiency of financial resources management at the local level, which can be ensured through the most efficient use of its resource potential;

- elimination of systemic violations of budget legislation and contradictory approaches to budget planning. To do this, one should move away from the practice of untimely adoption of the budget, anticipation of unrealistic budget parameters, which in turn create shortand long-term threats that cause a low level of budgetary security in the region;

- improving the control over the illegal/misuse of budget funds, budget accounting of budget execution, and cost estimates of budget institutions that will increase the transparency of the budget process and budget discipline. The depreciation of opportunities for inefficient use of local budgets will help inventory of existing programs while reducing their number, especially those that do not have specific per- 
formance indicators and do not have a dominant impact on socio-economic development of territories;

- formation of balanced local budgets (deficit-free), as this is, on the one hand, a guarantee of stable financing of the region's expenditures, on the other - a promise of debt accumulation (the level of budgetary security is inversely proportional to the budget deficit);

- stimulating the development of budget-forming industries and enterprises strategically crucial for the region, as this will contribute to the formation of a stable tax base of the territories.

\section{CONCLUSION}

The assessment confirmed the existence of different budget risks that may threaten financial security at both the regional and local levels, which ultimately affect the economic growth of the territories. Among the objective reasons is the strengthening of differentiation of development by socio-economic indicators (typical of regions and amalgamated hromada), due to their own financial and economic situation, the structure of the economy, the consequences of financial decentralization reform, military action in eastern Ukraine, inefficient use of budget funds, low quality of budget planning, etc. The obtained results allowed to differentiate levels of budgetary security of territories. The obtained results demonstrate the practicality and necessity of developing some measures to strengthen the budgetary security of the regions, which is especially important in the current conditions of increasing financial and economic instability, as budgetary security is not only the budgetary security of territories but also their ability to implement financial development policy. The reduction of budget risks will be facilitated by the formation of balanced local budgets (deficit-free). It is, on the one hand, is a guarantee of stable financing of territorial expenditures, on the other - a guarantee of debt accumulation (budgetary security is inversely proportional to the budget deficit). In addition, it is necessary to stimulate the development of budget-forming industries and strategically essential enterprises for the region, as this will contribute to the formation of a stable tax base of the territories.

\section{AUTHOR CONTRIBUTIONS}

Conceptualization: Halyna Voznyak.

Data curation: Taras Kloba, Lev Kloba.

Formal analysis: Halyna Voznyak, Taras Kloba.

Funding acquisition: Halyna Voznyak, Olha Mulska, Taras Kloba, Lev Kloba.

Investigation: Olha Mulska, Taras Kloba.

Methodology: Halyna Voznyak.

Project administration: Halyna Voznyak.

Resources: Halyna Voznyak, Olha Mulska, Taras Kloba, Lev Kloba.

Supervision: Halyna Voznyak.

Validation: Halyna Voznyak, Olha Mulska, Taras Kloba, Lev Kloba.

Visualization: Halyna Voznyak, Taras Kloba.

Writing - original draft: Halyna Voznyak.

Writing - review \& editing: Halyna Voznyak.

\section{ACKNOWLEDGMENTS}

The study has been conducted within the framework of Applied Research "Financial determinants of the provision of economic growth in the regions and Amalgamated hromada based on the behavioral economy" with the support of the National Research Foundation of Ukraine (M. Dolishniy Institute of Regional Research of National Academy of Sciences of Ukraine, the Grant Reg. No. 2020.02/0215, 2020-2022). 


\section{REFERENCES}

1. Babets, H. I., \& Ivakh, O. V. (2013). Metodychni pidkhody do otsiniuvannia biudzhetnoi bezpeky Ukrainy [Methodical approaches to the assessment of fiscal security of Ukraine]. Naukovyi visnyk NLTU Ukrainy - Scientific Bulletin of NLTU of Ukraine, 23(1), 204210. (In Ukrainian). Retrieved from https://nv.nltu.edu.ua/Archive/2013/23_1/204_Bab.pdf

2. Byhovchenko, V., \& Pichkur, A. (2019). Vykonannia derzhavnoho biudzhetu za vydatkamy [Execution of the state budget by expenditure]. Investytsiyi: Praktyka ta Dosvid - Investment: Practice and Experience, 20, 50-55. (In Ukrainian). https://doi.org/10.32702/23066814.2019.20.50

3. Cassar, G., \& Gibson, B. (2008). Budgets, Internal Reports, and Manager Forecast Accuracy. Contemporary Accounting Research, 25(3), 707-738. https://doi. org/10.1506/car.25.3.3

4. Cherniavska, O. V., Liu, Y.-R., Cherniavska, O. D., Khan, I., \& Zham, O. (2020). Scaling up Chengyu's role in Xi Jinping's government policies concept: From specific Chinese national, linguistic constructions up to markers and goals of the geoeconomic development strategy. International Journal of Management, 11(5), 185-194. Retrieved from https://papers.ssrn.com/sol3/ papers.cfm?abstract_id=3629022

5. Denek, E., \& Dylewski, M. (2013) Szacowanie poziomu zadłużenia jednostek samorzadu terytorialnego $w$ warunkach zwiększonego ryzyka utraty płynności finansowej [Estimating the level of indebtedness of local government units in the conditions of an increased risk of loss of financial liquidity]. Warszawa: Difin. (In Polish). Retrieved from https://ksiegarnia. difin.pl/szacowanie-poziomuzadluzenia-jednostek-samorzaduterytorialnego-w-warunkachzwiekszonego-ryzyka-utraty-plynnosci-finansowej1

6. Gorina, E. (2013). Financial Sustainability of Local Governments:
Effects of Government Structure,

Revenue Diversity, and Local Economic Base (Doctoral Dissertation). Arizona State University. Retrieved from https://repository. asu.edu/attachments/110575/content/Gorina_asu_0010E_12988. pdf

7. Heath, B. L., Ciarallo, F. W., \& Hill, R. R. (2013). An agent-based modeling approach to analyze the impact of warehouse congestion on cost and performance. The International Journal of Advanced Manufacturing Technology, 67(1-4), 563-574. http://doi.org/10.1007/ s00170-012-4505-5

8. Heiets, V. M., Kyzym, M. O., Klebanova, T. S., Cherniak, O. I., \& Bazhenova, O. (2006). Modeliuvannia ekonomichnoi bezpeky: derzhava, rehion, pidpryiemstvo [Modeling of economic security: state, region, enterprise]. Kharkiv: VD "INZHEK". (In Ukrainian).

9. Kafka, S., Kostin, O., Lutsenko, I., Liulchak, Z., Kuzmenko, H., \& Moskaliuk, H. (2019). Management and control model of organizational change in the process of monitoring financial results. International Journal of Recent Technology and Engineering, 8(3), 7261-7265. http://doi. org/10.35940/ijrte.C6340.098319

10. Karanina, E., Kyzyurov, M., \& Chuchkalova, S. (2020). Development of diagnostic tools and ensuring the financial and budgetary security of the region. E3S Web of Conferences 164, 09030. Retrieved from https://www.e3s-conferences. org/articles/e3sconf/pdf/2020/24/ e3sconf_tpacee2020_09030.pdf

11. Kolisnyk, O. I. (2011). Ekonomichna pryroda biudzhetnoi bezpeky derzhavy [The economic nature of state budgetary security]. Naukovi Zapysky - Scientific Notes, 16, 369377. (In Ukrainian). Retrieved from http://nbuv.gov.ua/UJRN/ Nznuoa_2011_16_51

12. Kuznetsova, S. A., Varenyk, V. M., \& Kokhan, M. O. (2014). Rozvytok derzhavnykh finansiv $v$ umovakh khaotychnoho strukturuvannia ekonomiky [Development of public finances in the conditions of chaotic economy structuring]. Kyiv: Center for Educational Literature. (In Ukrainian).

13. Kwilinski, A., Dielini, M., Mazuryk, O., Filippov, V., \& Kitseliuk, V. (2020). System Constructs for the Investment Security of a Country. Journal of Security and Sustainability Issues, 10(1), 345-358. https:// doi.org/10.9770/jssi.2020.10.1(25)

14. Londar, L. P. (2015). Borhovyi skladnyk finansovoi bezpeky Ukrainy: zahrozy ta indykatory [The debt component of financial security of Ukraine: threats and indicators]. Stratehichni Priorytety - Strategic Priorities, 2, 70-78. (In Ukrainian). Retrieved from http://nbuv.gov.ua/UJRN/ spa_2015_2_11

15. Lucianelli, G., Citro, F., Santis, S., Tranfaglia, A., \& Mazzillo, A. (2018). How to improve the financial conditions of local governments in a period of crisis: a descriptive case study. International Journal of Business and Management, 13(1), 53-69. https:// doi.org/10.5539/ijbm.v13n1p53

16. Lupak, R., Boiko, R., KunytskaIliash, M., \& Vasyltsiv, T. (2021). State management of import dependency and state's economic security ensuring: New analysis to evaluating and strategizing. Accounting, 7(4), 855-864. http:// dx.doi.org/10.5267/j.ac.2021.1.023

17. Lysiak, L., Kachula, S., Hrabchuk, O., Filipova, M., \& Kushnir, A. (2020). Assessment of financial sustainability of the local budgets: the case of Ukraine. Public and Municipal Finance, 9(1), 4859. http://dx.doi.org/10.21511/ pmf.09(1).2020.05

18. Pazdnykova, N., Kovsharov, A. \& Glazkova, N. (2019). Assessment of budgetary security of the region in the conditions of strategic transformations. Regionalnaya ekonomika. Yug Rossii - Regional Economy. The South of Russia, 7(1), 154-161. (In Russian). https://doi. org/10.15688/re.volsu.2019.1.14

19. Prokaziuk, O. V. (2016). Biudzhetna bezpeka derzhavy: 
sutnist ta osnovni zahrozy [State budgetary security: essence and main threats]. Finansovyi prostir - Financial space, 3(23), 39-45. (In Ukrainian). Retrieved from https://fp.cibs.ubs.edu.ua/index. $\mathrm{php/fp/article/view/476}$

20. Romenska, K., Chentsov, V., Rozhko, O., \& Uspalenko, V. (2020). Budget planning with the development of the budget process in Ukraine. Problems and Perspectives in Management, 18(2), 246260. http://dx.doi.org/10.21511/ ppm.18(2).2020.21

21. Rushchyshyn, N., Mulska, O., Nikolchuk, Y., Rushchyshyn, M., \& Vasyltsiv, T. (2021). The impact of banking sector development on economic growth: Comparative analysis of Ukraine and some EU countries. Investment Management and Financial Innovations, 18(2), 193-208. http://dx.doi. org/10.21511/imfi.18(2).2021.16

22. Shkarlet, S., Dubyna, M., Hrubliak, O., \& Zhavoronok, A. (2019). Theoretical and applied provisions of the research on the state budget deficit in Central and Eastern European countries. Administratie si Management Public, 32, 120-138. Retrieved from https://ramp.ase. ro/_data/files/articole/2019/32-09. pdf

23. Steccolini, I., Barbera, C., \& Jones, M. (2015). Governmental financial resilience under austerity: The case of English local authorities (CIMA Executive Summary Report). SDA Bocconi. Retrieved from https://competency.aicpa.org/ media_resources/208928-governmental-financial-resilience-underausterity/detail

24. Szarowská, I., Majerová, I., \& Šebestová, J. (2018). Indicators of financial stability for needs of municipalities. Českýfinanční a účetníčasopis, 13(1), 25-45. (In Czech). https://doi.org/10.18267/j. cfuc. 508

25. Varenyk, V. M. (2015). Otsinka biudzhetnoi bezpeky Ukrainy [Assessment of budgetary security of Ukraine]. Yevropeiskyi
Vektor Ekonomichnoho Rozvytku

- European Vector of Economic Development, 1(18), 33-43. (In Ukrainian). Retrieved from https://eurodev.duan.edu.ua/images/PDF/2015/1/5.pdf

26. Voznyak, H., \& Pelekhatyy, A. (2018). Participatory budgeting as a tool for the implementation of the fiscal policy of regional development of Ukraine. Economic Annals-XXI, 167(9-10), 53-56. https://doi.org/10.21003/ ea.V167-11

27. Voznyak, H., Kloba, T., Kloba, S., \& Kloba, L. (2019). Model of assessment of financial imbalances in regions of Ukraine. Investment Management and Financial Innovations, 16(1), 365377. https://dx.doi.org/10.21511/ imfi.16(1).2019.28

28. Wood, C., Thompson, D., \& Crampton, F. (2019). Budget Planning. In Money and Schools. New York: Routledge. https://doi org/10.4324/9780429449147-5 